Article

\title{
Evaluation of the Construction and Investment Process of a High-Pressure Gas Pipeline with Use of the Trenchless Method and Open Excavation Method. Analytic Hierarchy Process (AHP)
}

\author{
Urszula Kwast-Kotlarek ${ }^{1}$ and Maria Hełdak ${ }^{2, *}$ (]) \\ 1 Operator Gazociagów Przesyłowych GAZ-SYSTEM S. A. Oddział we Wrocławiu, 50-513 Wrocław, Poland; \\ uk5@gazeta.pl \\ 2 Department of Spatial Economy, Wrocław University of Environmental and Life Sciences, \\ 50-375 Wrocław, Poland \\ * Correspondence: maria.heldak@upwr.edu.pl
}

Received: 28 February 2019; Accepted: 18 April 2019; Published: 24 April 2019

check for updates

\begin{abstract}
The study presents the application of multi-criteria analysis, i.e., the Analytic Hierarchy Process (AHP), for the evaluation of investments related to the realisation of a high-pressure gas pipeline. The authors evaluated the realisation of the gas pipeline with the use of alternative methods: the trenchless Horizontal Directional Drilling (HDD) method and the open excavation method, based on the example of the construction of a high-pressure gas pipeline DN1000. Sections located in naturally valuable areas on the route of the pipeline Wierzchowice-Kiełczów (Poland) were analysed, on the section from the valve station in Czeszów to the Kiełczów node. The research considered the following criteria: technical costs, economic costs, social costs, and environmental costs. The sum of these partial estimations is the "total cost" of the investment. Research revealed that the technical costs of the open excavation method are in all cases higher than the technological costs of the trenchless method during the realisation of a gas pipeline (in the AHP analysis, they receive an average score of -4 or -3 , compared to a score of -2 for the HDD method). On the other hand, the economic costs are comparable, with a slight advantage for the HDD method. The overall score for the open excavation method obtained with use of the AHP multi-criteria evaluation is, for different variants, approximately -19 , while the evaluation of the realisation of a gas pipeline with use of the Horizontal Directional Drilling method gives a score from -15 to -10 , depending on the section.
\end{abstract}

Keywords: Analytic Hierarchy Process (AHP); horizontal directional drilling (HDD); open excavation; naturally valuable areas; investment evaluation

\section{Introduction}

The realisation of any construction investment in the so-called construction and investment process results in a certain degree of interference with the surrounding environment. The decision on the selection of a method used for the construction of gas pipelines in areas that are protected due to their natural values may be based on the Analytic Hierarchy Process (AHP). It is a useful tool that considers several criteria necessary to make the right choice from among alternative methods of realisation of the investment. AHP is a powerful technique which supports decision making in a multi-attribute environment [1,2]. It allows the creation of an understandable hierarchical model by the decomposition of complex problems [3]. 
The Analytical Hierarchy Process is one of the heuristic methods developed by the American mathematician T. L. Saaty that combines elements of mathematics and psychology. It was described in previous study, among others [4-8].

Apart from its applications in economics, it is also used in technical sciences, such as in safety assessment; for instance [9], in discussing how group decision-making methods can be used in the design of railway infrastructure and in air traffic safety [10]. This method enables the evaluation of decision variants based on defined criteria by means of determining the relative weights that reflect the usability of the variants for each criterion. The final score is a result of aggregating individual usability values. This method is used to rank a finite number of decision variants, which are usually evaluated according to numerous criteria.

According to Roszkowska [11], multi-criteria decision-making techniques are useful tools to help the decision maker(s) to select options in the case of discrete problems. They have found great acceptance in many areas of decision-making processes in economy and management. Among many multi-criteria techniques, aside to the AHP method, are SAW (Simple Additive Weighting), SMART (The Simple Multi Attribute Rating Technique), TOPSIS (Technique for Order Preference by Similarity to an Ideal Solution), ELECTRE (Elimination and Choice Expressing Reality). The TOPSIS technique selects the alternative closest to the ideal solution and farthest from the negative ideal alternative. The classical TOPSIS method is based on information on attributes from the decision maker and numerical data; the solution is aimed at evaluation, prioritisation and selection, and the only subjective inputs are weights. This the technique is used to rank for order performance by similarity to the ideal solution [11-13].

The TOPSIS method is based on determining the distance of the analysed objects from the positive ideal solution (PIS) and the negative ideal solution (NIS). The final outcome of the analysis is a synthetic indicator that creates a ranking of the analysed objects. The chosen alternative should have the shortest distance from the positive ideal solution and the longest distance from the negative ideal solution [14].

It is one of the most popular methods of solving multicriteria discreet tasks. The analysed decision variants are compared with abstract weighed reference solutions-the positive ideal solution and the negative ideal solution. Determining the ranking requires accounting for the weights of criteria, normalisation, and the selected metrics to calculate the distance from the given variant of the decision solution to the reference solutions, and to find the value of the synthetic indicator that prepares the final ranking for each analysed variant [15].

The reference points are the positive ideal solution and negative ideal solution. Sets of reference points specified by the decision maker are also considered. In the TOPSIS (Technique for Order Preference by Similarity to Ideal Solution) method [16-18], the most preferred alternative should be characterised by the shortest distance from the weighed positive ideal solution and the longest distance from the weighed negative ideal solution.

If the problem is not defined precisely, the fuzzy version of the method may be applied (FTOPSIS, Fuzzy TOPSIS) [19]. According to Trzaskowski, this modified TOPSIS method is predisposed to support bilateral negotiations. Another method that consists in the assessment of variants according to their distance from the positive ideal and negative ideal solutions, is the VIKOR method (Serbian: VIskrzterijumska Optimizacija i Kompromisno Resenje) [20].

The values of the following parameters are calculated for each decision variant: weighted average distance from the positive ideal solution and weighted maximum distance from the positive ideal solution. When making a decision, we may balance between the average and maximum values.

Another group of methods based on outranking relations are the PROMETHEE (Preference Ranking Organisation METHod for Enrichment Evaluations) methods. The preferences of the decision maker are modelled with the use of fuzzy preference functions, whose arguments are the differences in the evaluation of the pairs of the analysed decision variants. The characteristics of the PROMETHEE methods are aggregated preference indices that are the basis for calculating dominance flows, both positive and negative. In the PROMETHEE I method these flows are the basis for the final result, which is a partial ranking of decision variants. In the PROMETHEE II method, the net flow of dominance is 
calculated, which allows one to obtain a complete order, which in turn enables us to determine the ranking of the analysed variants. The EXPROM (EXtension of the PROMethee method) methods are a modification of the PROMETHEE family of methods [20].

Additive methods include the SAW (Simple Additive Weighting Method) method, which is the most well-known and most commonly used multi-criteria discreet method, the F-SAW (Fuzzy Simple Additive Weighing) method [21], and the SMART (Simple Multi-Attribute Ranking Technique Method) and SMARTER (Simple Multi-Attribute Ranking Technique Exploiting Ranks) methods [22]. The algorithm is the same as in the SMART method. Modifications are connected with variant evaluation (value functions are linear) and by the manner of weight determination-ROC (Rank Order Distribution) weights are often used, depending on the number of analysed criteria.

The usefulness of the multicriteria discreet decision aid methods was assessed by Trzaskalik $[15,20]$ and Zalewski [23].

The discreet multi-criteria methods listed above may be used for:

- $\quad$ selecting projects co-financed from European Union funds (SAW, EXPROM),

- $\quad$ supporting bilateral negotiations (F-SAW, F-TOPSIS),

- $\quad$ selection of employees (AHP, PROMETHEE II).

The selection of the multi-criteria method to be used in a specific decision-making problem is a multi-criteria problem in itself. Thus, certain proposals have been made to support the decision maker in this respect. They include the Gershon and Teckle models [24]. In both cases, the final choice is made with use of compromise programming. It is worth noting that these proposed solutions cannot replace a qualitative analysis of the problem and may only complement it.

AHP is a method used in risk management and decision processes $[25,26]$. In environmental research, it is used for evaluating sustainable development of the environment and in making environmental decisions [27]. It may be employed in waste management [28]. AHP was also used as a decision-making methodology in forest management supervision, water resources management, in the selection of oil fields, and in renewable energy in numerous countries [29-31]. Moreover, AHP is also the basis for making critical long-term decisions, such as choosing the places to deposit hazardous waste, long-term irreversible decisions, and long-term investments of the European Union [32,33].

Saaty has used AHP since its introduction in 1980 for a large number of Multiple Criteria Decision Making(MCDM) projects, industries, and applications [34,35]. Saaty used the AHP for applications such as setting priorities, risk management, quality management, project management, and strategic decision-making. The AHP is suitable for hardware and software related decisions, as well as using inputs from literature reviews, databases, and experts [36].

The advantages of using AHP include [37]:

- $\quad$ the ability to capture quantitative and qualitative attributes in a simple way $[38,39]$;

- $\quad$ popularity $[40,41]$;

- $\quad$ simple implementation and interpretation [42,43];

- ability to cope with rare or poor-quality data [39];

- compliance test in order to ensure certificate quality [3].

The aim of the paper is to evaluate the realisation of sections of a high-pressure gas pipeline in naturally valuable areas with use of the multi-criteria decision-making method Analytic Hierarchy Process (AHP) and to select the appropriate variant of the technology of investment realisation. The subject of the evaluation was the application of alternative methods, including the open excavation method and the trenchless Horizontal Directional Drilling (HDD) method in the course of realisation of the sections of the Wierzchowice-Kiełczów gas pipeline from the valve station Czeszów to the Kiełczów node (Poland).

Horizontal Directional Drilling (HDD) is a modern technology (classified as one of the so-called trenchless methods) that consists of conducting horizontal directional drilling. Horizontal drilling is a 
type of directional drilling. Horizontal directional drilling enables the construction of various types of installations (water supply pipes, sewage systems, gas supply pipes, power supply lines) with use of the trenchless method in all locations where it is impossible to construct an open trench for pipes or cables $[44,45]$.

HDD drilling consists of several stages of works that take place directly one after another. These stages are as follows:

1. Pilot drilling. The drilling is performed with use of the drilling rig, drill string, drilling tools, and a navigation system. The circulation system of the drilling fluid is closed.

2. Drilling diameter expansion.

3. Installation of the carrier pipe. The pipe is placed on rollers, and then it is fastened to a swivel and pulled into the drilling borehole with use of the drilling rig and the drill [44].

Similarly, as in the publication by Ariaratnam [46], the main goal is to search for viable technologies that enable to reduce the costs and to ensure environmental benefits. In Poland, a majority of the installation, inspection, repair and maintenance works of underground equipment are still performed with use of traditional methods, i.e., construction technologies based on excavations. The works are often costly and the constructors must perform the excavation works very carefully in order to avoid damages to the existing underground infrastructure, which in turn slows down the work. Apart from these costs, excavation works also generate so-called social costs, caused by traffic disruption or negative influence on local businesses. Similar negative consequences may be observed with respect to natural habitats or ecological corridors.

\section{Research Methodology}

The paper presents the possibility of using the multi-criteria decision-making method Analytic Hierarchy Process (AHP) in order to select a variant of realisation of sections of a high-pressure gas pipeline in naturally valuable areas. AHP enables the qualitative and quantitative assessment of the specified variants. The present study refers to the practical application of the AHP (Analytic Hierarchy Process) method based on the example of the construction of the Wierzchowice-Kiełczów (Poland) high-pressure gas pipeline DN1000, focusing on the Czeszów-Kiełczów section. The pipeline is approximately $32.5 \mathrm{~km}$ long and it has a diameter of $1000 \mathrm{~mm}$. It is located in the Lower Silesian Voivodeship, in the Zawonia and Długołeka municipalities. As it constitutes a part of the North-South Gas Corridor, it will ultimately enable full integration of gas transfer infrastructure in this part of Europe.

The selection of a multi-criteria discreet decision aid method to choose the variant of realisation of a high-pressure gas pipeline was very difficult. The main factor in selecting the method was the possibility to simplify it, so that it may be used more widely at the stage of the environmental impact forecast. During the process of selecting a technology for the realisation of a gas pipeline we must deal with multi-criteria decision issues of various natures. Among numerous problems that were listed by Chojnacki and Szwedo [47], the following may be specified.

1. The existence of numerous objectives or attributes (the decision maker has to define the set of objectives or attributes that will be suitable for the analysed decision-making issue).

2. Lack of a universal measure for the criteria-each of the objectives or attributes may have a different measurement unit. The existence of both quantitative criteria (estimated directly) and qualitative criteria (presented verbally), which, in practice, often play the main role in the decision-making process.

3. The issue of searching for the best solution or selecting the best variant from among a small number of variants.

4. The decision-making process takes place in the conditions of missing information or information of an uncertain (fuzzy, probabilistic) nature. 
5. The need to realise the decision-making process in a relatively short time and by a small number of decision makers.

6. One-off choice (at least for the period of operation of the gas pipeline- -even up to several decades), i.e., for the life cycle of the system).

The popularity of the AHP method and the performed detailed analysis confirmed the authors' conviction that the AHP method was the best available method for analysis, apart from the aforementioned TOPSIS method. However, the advancement of the works realised at that time convinced us to continue research according to the predefined schedule.

The research compared two alternative variants of the realisation of the investment:

- with use of the open excavation method,

- with use of the trenchless Horizontal Directional Drilling (HDD) method.

Trenchless technologies are becoming an increasingly accepted alternative for traditional open excavation methods. Owners of infrastructure are searching for cost-efficient strategies and technologies in an attempt to reduce expenditure [46]. The comparison of the methods of network realisation results from the variants of investment realisation proposed by the contractor. The investor is looking for a basis that would justify the application of the horizontal directional drilling (HDD) method. Here, the multi-criteria analysis is a tool that supports the decision-making process.

The method of study follows the following steps:

- determination of the subject and selection of study area;

- analysis of scientific literature;

- collecting information-terrain inventory and preparation of ecophysiographic data for the analysed sections of high-pressure gas pipeline;

- defining the evaluation criteria and the scale of weights adopted for the study, as well as assigning numerical scores to verbal assessments;

- comparing pairs of variants and criteria together with verbal assessment connected with the preferences of the decision maker;

- supporting the decision maker by assigning numerical values used for calculations to verbal assessments.

The authors set the following research questions:

Q1: Are the technological and economic costs of the application of the open excavation method used in the construction of a high-pressure gas pipeline really lower than in the horizontal directional drilling (HDD) method, with higher environmental costs?

Q2: Can the environmental and social costs of constructing high-pressure gas pipelines influence the decision on the application of the trenchless method (horizontal directional drilling (HDD)) for the construction of gas pipelines in naturally valuable areas?

The main aim of the conducted analysis is to determine which of the installation techniques is the most appropriate from the point of view of project participants, including the public and private sector, taking into account important environmental, ecological, economic, technological, and social factors. The first step of the analysis is to define the structure of the hierarchy that reflects the problem. The general criteria considered during the comparison are:

- technological costs,

- economic costs,

- social costs,

- environmental costs. 
The sum of these partial estimations is the "total cost" of the investment.

The analyses refer to the sections of the gas pipeline planned to be constructed in naturally valuable areas. The assessment of the alternative solutions for the investment refers to the sections described below (Table 1).

The route of the gas pipeline, together with the locations of the planned HDD drillings, are presented in the illustration (Figure 1).

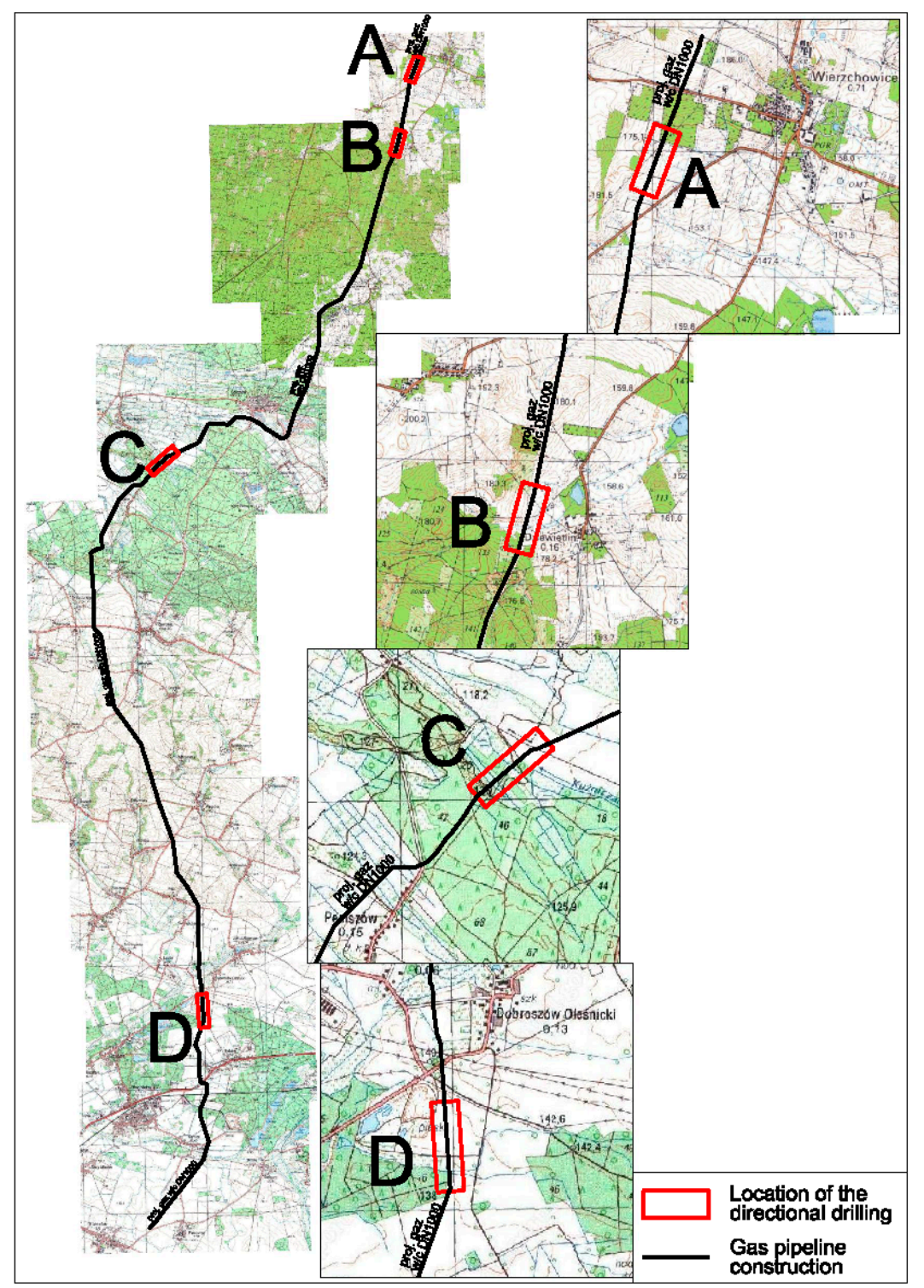

Figure 1. Route of the high-pressure gas pipeline Czeszów-Kiełczów, together with the locations of the planned Horizontal Directional Drilling (HDD).

The essence of the AHP method is the comparison of pairs of the analysed decision variants in terms of all evaluation criteria. These comparisons are made with use of special evaluation tables for each of the criteria based on a defined scoring scale.

This paper proposes assigning numerical scores to verbal assessments in a slightly different way than the one originally proposed by Saaty [1]. The AHP method functions based on alternatives and goals that are important for the decision and it takes into account qualitative and quantitative criteria. This is important, as some of the criteria are difficult to assess in quantitative terms (e.g., the environmental impact). In order to obtain the score, various pieces of information are juxtaposed to 
confirm the significance of the decision. Saaty introduced a scale of 9 values. This scale also covers an important element, namely the reverse values of the scale. If an element is 3 times as important as another one, it means that the other element has a value of one-third. The indirect preference (evaluation) was presented in the form of numbers $(6,7,8$, and 9 ) to enable unambiguous classification of the score and to complement the scale set to obtain clear information for the decision criteria. Reciprocal values were not used to demonstrate the advantage of one assessment or judgment over another, in the form of the reciprocal of the score that would be assigned to the second criterion when compared with the first one, e.g., one-fifth (Table 2).

Table 1. Sections of the constructed high-pressure gas pipeline, for which alternative methods of realisation (with use of the trenchless method or the open excavation method) were considered.

\begin{tabular}{|c|c|c|}
\hline $\begin{array}{l}\text { Section } \\
\text { ID }\end{array}$ & $\begin{array}{c}\text { Approximate } \\
\text { Length, Location }\end{array}$ & Description of the Natural Values \\
\hline A & $\begin{array}{c}\mathrm{km} 10+330- \\
10+515\end{array}$ & $\begin{array}{l}\text { An approximately } 185 \text { m long section, covering a eutrophic reservoir } 3150 \text { with yellow } \\
\text { water-lilies, surrounded by reed rushes. Breeding places of the grass frog (Rana temporaria), } \\
\text { common water frog (Rana esculenta), and common toad (Bufo bufo). Habitat of the mallard (Anas } \\
\text { platyrhynchos) and great reed warbler (Acrocephalus arundinaceus), and probably the breeding } \\
\text { place of common pochard (Aythya farina), tufted duck (Aythya fuligula), little grebe (Tachybaptus } \\
\text { ruficollis), common grasshopper warbler (Locustella naevia), and Eurasian red warbler } \\
\text { (Acrocephalus scirpaceus). Breeding of sedge warbler (Acrocephalus schoenobaenus) is also possible. } \\
\text { To the E from the pond there are riparian woods with grey alder (Alnus incana) *91E0-3 along } \\
\text { the Struga water course. Probably the breeding place of bluethroat (Luscinia svecica) (a species } \\
\text { from Anndex I of the Birds Directive) and of numerous other bird species. Habitat of viviparous } \\
\text { lizard (Zootoca vivipara) and grass snake (Natrix natrix). }\end{array}$ \\
\hline B & $\begin{array}{l}\mathrm{km} 12+830- \\
13+126\end{array}$ & $\begin{array}{l}\text { An approximately } 300 \mathrm{~m} \text { long section, covering a mosaic of meadows and single shrubs, which } \\
\text { is the habitat of numerous animal species. Habitat of a rare plant-mouse garlic (Allium } \\
\text { angulosum L.). }\end{array}$ \\
\hline $\mathrm{D}$ & $\begin{array}{c}\mathrm{km} 24+000- \\
24+700\end{array}$ & $\begin{array}{c}\text { An approximately } 650 \mathrm{~m} \text { long section, covering alluvial forests with Alnus glutinosa and } \\
\text { Fraxinus excelsior and alder swamps 91E0* (approx. } 2.91 \mathrm{ha} \text { ). A } 250 \mathrm{~m} \text { wide belt along the } \\
\text { pipeline-part of the Natura } 2000 \text { area Kumaki Dobrej and a marsh or flooded meadow near the } \\
\text { forest. }\end{array}$ \\
\hline
\end{tabular}

Source: Own study.

Table 2. Assignment of numerical scores to verbal assessments.

\begin{tabular}{cc}
\hline Verbal Assessment & Numerical Score \\
\hline Extreme & 5 \\
\hline Very strongly & 4 \\
\hline Strongly & 3 \\
\hline Moderately & 2 \\
\hline Equivalently & 1 \\
\hline Indirect preference & $6,7,8,9$ \\
\hline Reverse preference & Reciprocal of the number \\
\hline \multicolumn{2}{c}{ Own study based on Saaty (1980). }
\end{tabular}

The authors of the present article do not reference the full AHP methodology, as it does not recreate the fundamental mathematical procedure.

In the analysed example, the authors did not have an opportunity to monitor the design planning phase, and the presented analysis of the selection of one of the methods to construct the gas pipeline only points to the weights that might lead to changing the decision while performing the works. The evaluation referred to sets of parameters, whose only aim was to explain the procedure in the decision-making method. The following factors (evaluation criteria) and weight scale, depending on the characteristics of the investment, were used in research (Table 3). 
Table 3. List of the evaluation criteria and weight scale applied in the study.

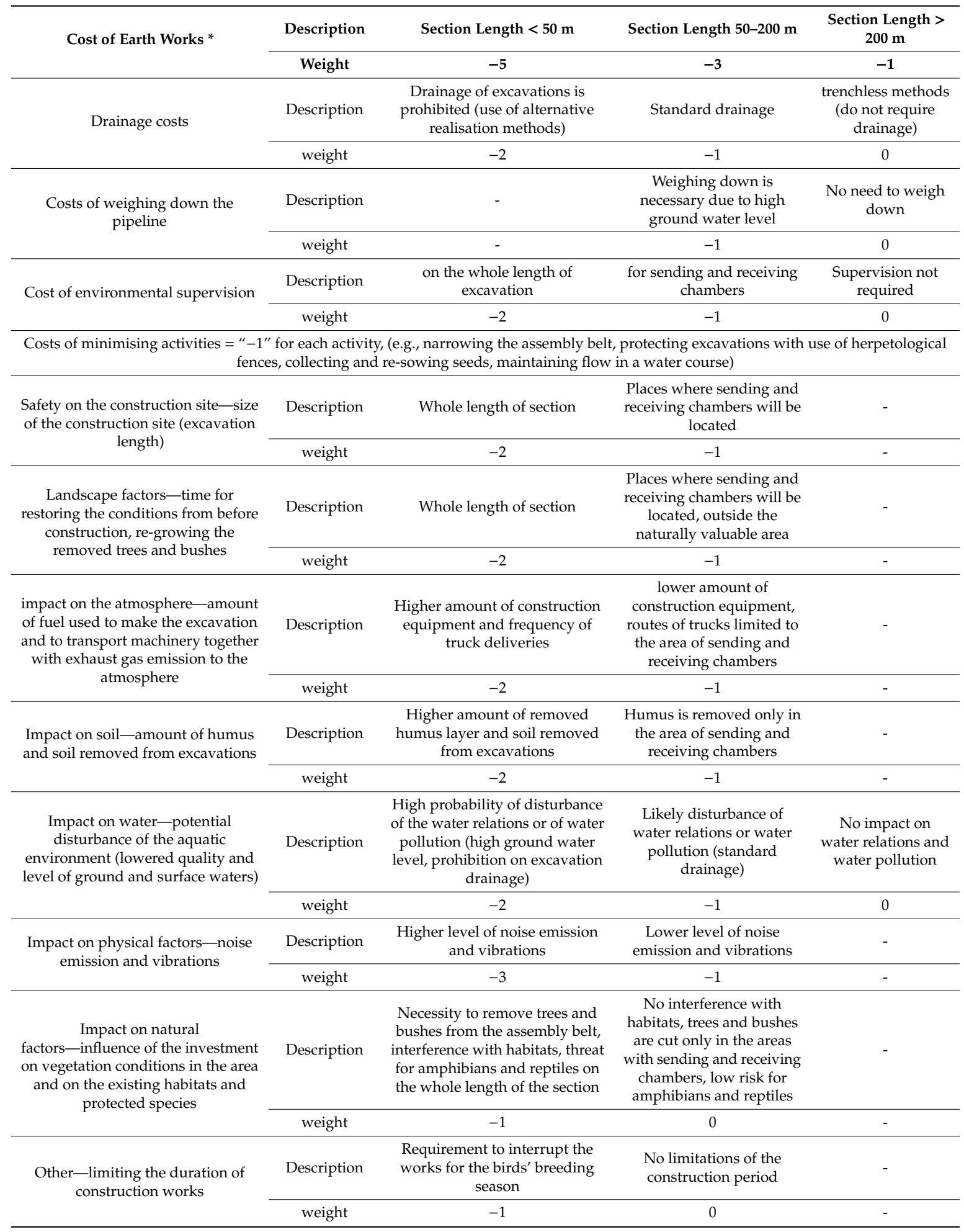

Note: * Ratio of unit costs for trenchless realisation to unit costs for realisation with use of the excavation method.

Specific criteria were assigned weights depending on the degree of their influence on the costs of realising the investment with use of the selected open-excavation or trenchless method, based on the assumption that in both cases, the same goal should be achieved, i.e., the lowest negative environmental impact possible. In the assessment process during decision-making, the following set of numbers was used: $\{-9,-8,-7,-6,-5,-4,-3,-2,-1,0\}$. According to the Authors of the 
paper, the number " 0 " signifies a neutral influence on the decision. Adopting the scale from -9 to 0 demonstrates that each aspect of the problems was treated as very important, assuming an inaccuracy of the assessment. The use of the "-" symbol for criteria and not assigning weights to some of the elements were mentioned for the trenchless method, because omitting any aspects of the problem at the stage of analysing the issue may lead to results that are not completely satisfactory for the person who makes the decision.

The complete evaluation of variants based on the AHP procedure should include the creation of a vector of scale for specific matrices (assessment table), and the calculation of the consistency ratio (CR) of the assessments, which was intentionally omitted by the authors in order to maintain the clarity of the example. The detailed algorithm may be found, among others, in the original publication by Saaty [1].

\section{Results and Discussion}

3.1. Characteristics of the Realisation of the Investment with Use of the Horizontal Directional Drilling Method (HDD) and Open Excavation Method

On the Czeszów-Kiełczów section of the pipeline, several crossings were designed to be constructed with use of the trenchless method. The total length of these crossings is $3100 \mathrm{~m}$, including drillings under roads and water courses, namely, the ponds and the Śleczka stream in Czeszow, the Jasionka stream and drainage ditch in Łazy Małe, forest water courses in Pierstnica, the ponds in Dziewiętlin and Świebodow and the drainage ditch in Wierzchowice, as well as the Sasiecznica, Dobra, and Topór rivers.

Crossing a water course with use of the trenchless method does not cause devastation of the banks and the vegetation overgrowing them. Works are performed away from the stabilised shore line, without interrupting water flow and disturbing the existing biological life. This type of river crossing avoids disturbances of flow in the water course bed.

Horizontal Directional Drilling (HDD) is a modern technology (classified as one of the so-called trenchless methods) that consists of conducting horizontal directional drilling. It is a type of directional drilling. Horizontal directional drilling enables the construction of various types of installations (water supply pipes, sewage systems, gas supply pipes, and power supply lines) with use of the trenchless method in all locations where it is impossible to construct open trenches for pipes or cables [40]. The stage that precedes the widening of the pilot hole and the installation of the technological pipe in the HDD method is called the pilot drilling. Works are conducted with drilling equipment with use of the techniques of soil washing, mining with a stream of drilling fluid, or with a depth engine with a roller drill [41].

The drilling process requires the use of large amounts of drilling liquid, whose main aims are to discharge the spoils, lower the friction forces, and stabilise the hole. Drilling liquid is prepared from water from the crossed river, water course, or ditch; water may also be obtained from the supply network. The use of a drilling liquid recovery system significantly limits the consumption of water used for drilling. A large amount of the water is returned to the environment in the form of gauging water of the suspension mass that creates the structure of the hole.

The open excavation method is used mainly in agricultural areas. For the discussed gas pipeline, the width of the construction belt is 30-33 m or less, depending on the terrain conditions. The excavation technology requires the removal of the humus layer and laying it aside, outside the construction zone. The removed humus is stored separately from the remaining soil from the trench. Humus is deposited inside the construction belt in a manner that enables using it for reclamation works. After the construction is completed, the excavation trench is filled with layers of soil. The previously removed humus is then replaced as the top layer. After the gas pipeline has been constructed, agricultural lands are reclaimed and restored to their original state so that they can continue to be used according to their original designation. 
In wooded areas, where the pipeline is also constructed with use of the open-cut method, the width of the construction belt (i.e., temporary cutting of bushes and trees) is approximately $27 \mathrm{~m}$, and the width of permanent removal of trees (the belt excluded from forest production) is $4 \mathrm{~m}$, divided into two $2 \mathrm{~m}$ wide zones from the axis of the gas pipeline to the trunks of trees or bushes. The remaining forest area occupied for the duration of the construction may be reforested and returned to forest production. If the trenchless method (e.g., the horizontal directional drilling method) is used in wooded areas, cutting of trees and bushes is not required. In such event, the gas pipeline should be laid below the root systems of the trees. The aim of narrowing the construction belt to approximately $27 \mathrm{~m}$ is to reduce the intervention of construction equipment and humans in the vicinity of existing forest complexes to a minimum.

\subsection{Characteristics of the Pipes, and the Technological, Economic, Social, and Environmental Costs of the Evaluated Investment}

\subsubsection{Technological Costs}

Technological costs include the installation of pipes, consisting of the total economic means necessary perform the physical work and restore the site of the investment after completion.

Sections for which variant analysis has been conducted are not highly urbanised areas with a dense underground infrastructure. Thus, the investor did not incur increased costs connected with occupying a lane of traffic or the change in traffic organisation for the duration of the works. The designated areas are generally uninhabited and undeveloped, so the only criterion in the analysis are their high natural values, which are also influenced by local soil and water conditions (areas with a high ground water level or even wetlands) and the fact that they are home to habitats of protected species.

Technological costs include the installation of pipes, consisting of the total economic means necessary to perform the physical labour and restore the site of the investment after completion. In each case, the technological costs of the open excavation method that consists of the costs of earth works, drainage, and costs of weighing down the pipeline received a lower score than the technological costs of the HDD method during the realisation of the gas pipeline (lower scores in criteria assessment; Table 4) [48].

\subsubsection{Economic Cost}

The economic costs are expenditures on materials, machinery, and works not directly connected with the construction process. The analysis takes into account the following costs:

- cots of damage to private property;

- costs of damage to adjacent infrastructure;

- costs of damage and wear of road surface;

- costs resulting from increased expenditure on road maintenance;

- costs of moving the existing infrastructure that interferes with the construction works;

- costs of environmental supervision and actions to minimise negative impact.

Due to the fact that the analysed sections of the investment are located in naturally valuable areas, the only criterion for both construction methods will be the costs of environmental supervision and of actions minimising the negative environmental impact of the investment. Excavation methods are characterised by low costs of construction and material purchase and the long duration of the conducted works, which depends, among other factors, on the atmospheric conditions. At the same time, the costs of recreating the area and restoring the land to the previous condition without changing its manner of use are high. In the trenchless method, the main cost-generating factor is the applied technology, earth works, surface works, and the costs of occupying a lane of traffic. 
Table 4. Comparison of the variants of realisation of selected sections of the gas pipeline: A and B are pipeline sections from valve station Czeszów to the Kiełczów node.

\begin{tabular}{|c|c|c|c|c|c|}
\hline \multirow{2}{*}{\multicolumn{2}{|c|}{ Realisation Variant }} & \multicolumn{4}{|c|}{ Areas for Which Variants of Realisation Were Considered } \\
\hline & & Open Excavation Method & Trenchless Method & Open Excavation Method & Trenchless Method \\
\hline & Section ID & \multicolumn{2}{|c|}{ A } & \multicolumn{2}{|l|}{ B } \\
\hline \multicolumn{2}{|r|}{ Evaluation criterion } & \multicolumn{4}{|c|}{ Weights } \\
\hline \multirow{2}{*}{ 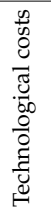 } & Cost of earth works & 0 & -3 & 0 & -1 \\
\hline & $\begin{array}{l}\text { Costs of weighing } \\
\text { down the pipeline }\end{array}$ & -1 & 0 & -1 & 0 \\
\hline 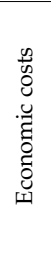 & $\begin{array}{l}\text { Cost of environmental } \\
\text { supervision }\end{array}$ & -1 & -1 & -1 & -1 \\
\hline \multirow{2}{*}{$\begin{array}{l}\frac{0}{0} \\
0 \\
0 \\
.0 \\
0 \\
0 \\
\infty\end{array}$} & $\begin{array}{l}\text { Safety issues in the } \\
\text { vicinity of the } \\
\text { construction site }\end{array}$ & -2 & -1 & -2 & -1 \\
\hline & Landscape factors & -1 & 0 & -1 & 0 \\
\hline \multirow{4}{*}{ 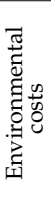 } & Air & -2 & -1 & -2 & -1 \\
\hline & Soil & -2 & -1 & -2 & -1 \\
\hline & Water & -1 & 0 & -1 & 0 \\
\hline & Physical factors & -1 & -3 & -1 & -3 \\
\hline & TOTAL WEIGHTS & -19 & -15 & -18 & -10 \\
\hline
\end{tabular}

\subsubsection{Social Costs}

Social costs are the costs incurred by the local community during the duration of the investment project. They refer to such external issues as any barriers or obstacles in the economic activity in the area adjacent to the project site. The following costs are taken into account:

- traffic organisation problems;

- safety issues in the vicinity of the construction site;

- interference with commercial and recreational activity in the project area;

- landscape factors;

- human factors (connected with the negative influence of the investment-related works on the inhabitants of the neighbouring areas).

Similarly, as in the case of economic costs, and also the social costs with respect to traffic organisation, disrupting commercial and recreational activities and the human factors for the analysed sections are comparable in all aspects, i.e., they will be non-existent or negligible. The work safety aspect refers to the costs incurred by contractors and the community to ensure the safety of workers on the construction site. The fourth item that refers to landscape factors must be considered, taking into account the negative influence of the investment on the "landscape values" of the selected area. 


\subsubsection{Environmental Costs}

The environmental costs are used to evaluate the permanent destructive influence on the elements of the natural environment in the area of the investment. For the purposes of the analysis, this factor is divided into five criteria of the same importance:

- air,

- soil,

- water,

- physical factors,

- natural factors.

As far as air is concerned, the open excavation method was considered more harmful than the trenchless alternative due to increased fuel consumption required to excavate a large trench and for the transport of machinery, which also entails higher emission of exhaust gases.

The open excavation also has a higher influence on soil than the trenchless methods, although the latter required more numerous and thorough geological and geotechnical analyses before the commencement of the investment project.

Potential interference with the aquatic environment, such as deteriorated quality of both ground and surface waters, was also taken into account during the analysis of both construction options. Here, the open excavation may also have a greater influence on ground waters than the trenchless method and it may disrupt the circulation of surface waters (for the duration of construction works).

Physical factors connected with the influence of the construction process on the life of local residents (including also the animals and birds) are caused by noise and vibrations, while natural factors refer to the influence of the investment on vegetation conditions in the area, as well as on the existing habitats and protected species. In both cases, the trenchless method is much more beneficial than the open cut method.

In difficult situations, such as deep pipeline laying or in the case of crossing highways, rivers, or lakes, HDD can be not only more cost effective, but also more feasible and applicable than any other trenchless method [49,50].

Trenchless technologies may lead to a significant reduction in the emission of exhaust gas in comparison to traditional open excavation methods. The comparison of the trenchless method of pipe bursting with the traditional open excavation method revealed that the application of trenchless technology reduced gas emission to the atmosphere by $80 \%$. This is an important property of trenchless methods in terms of their market competitiveness, especially considering the tendency to increase environmental efficiency $[46,47,51]$.

\subsection{Comparison of Alternative Methods of the Realisation of Gas Pipeline}

To compare both methods, the detailed value of each cost must be determined. The used Analytical Hierarchy Process (AHP) focused on the issue of protecting naturally valuable areas that had been identified during the previous inventory for the specific investment, consisting of the construction of high-pressure gas pipeline.

Additionally, the analysis took into account the schedule of realisation of the investment.

Specific criteria were assigned weights depending on the degree of their influence on the costs of realising the investment with use of the selected method, based on the assumption that in both cases, the same goal should be achieved, i.e., the lowest negative environmental impact possible.

The tables below present the variant analysis for the selected sections of the pipeline (Tables 4 and 5).

The above table demonstrates that for each of the analysed sections, the sum of weights of the cost of the realisation of the investment with use of the open excavation method is lower than in the case of using the trenchless methods. These differences range from -3 to -8 points, depending 
on the length of the section and the type of terrain (mainly the level of ground waters and natural values). This means that the total costs of the project (understood in a broader sense than just financial expenses) for excavation methods are higher. Thus, limiting their negative impact requires higher financial expenditure and restoring the environment to the original condition takes much longer than for trenchless methods.

Table 5. Comparison of the variants of realisation of selected sections of the gas pipeline. C and D are pipeline sections from valve station Czeszów to the Kiełczów node.

\begin{tabular}{|c|c|c|c|c|c|}
\hline \multirow{2}{*}{\multicolumn{2}{|c|}{ Realisation Variant }} & \multicolumn{4}{|c|}{ Areas for Which Variants of Realisation Were Considered } \\
\hline & & $\begin{array}{c}\text { Open Excavation } \\
\text { Method }\end{array}$ & Trenchless Method & $\begin{array}{c}\text { Open Excavation } \\
\text { Method }\end{array}$ & Trenchless Method \\
\hline \multicolumn{2}{|r|}{$\begin{array}{l}\text { Approx. Length of the } \\
\text { Section }\end{array}$} & \multicolumn{2}{|c|}{ Approx. km $4+600-5+050$} & \multicolumn{2}{|c|}{ Approx. km $24+000-24+700$} \\
\hline & Section ID & \multicolumn{2}{|c|}{$\mathrm{C}$} & \multicolumn{2}{|c|}{$\mathrm{D}$} \\
\hline \multicolumn{2}{|r|}{ Evaluation criterion } & \multicolumn{4}{|c|}{ Weights } \\
\hline \multirow{3}{*}{ 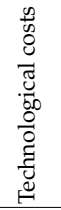 } & Cost of earth works & 0 & -1 & 0 & -1 \\
\hline & Drainage costs & $\begin{array}{l}\text { Trench drainage } \\
\text { prohibited } \\
-2\end{array}$ & 0 & $\begin{array}{c}\text { Trench drainage } \\
\text { prohibited } \\
-2\end{array}$ & 0 \\
\hline & $\begin{array}{l}\text { Costs of weighing } \\
\text { down the pipeline }\end{array}$ & -1 & 0 & -1 & 0 \\
\hline \multirow[b]{2}{*}{ 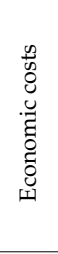 } & $\begin{array}{l}\text { Cost of environmental } \\
\text { supervision }\end{array}$ & -1 & -1 & -1 & -1 \\
\hline & $\begin{array}{l}\text { Cost of actions } \\
\text { minimising the } \\
\text { negative } \\
\text { environmental impact } \\
\text { of the investment }\end{array}$ & $\begin{array}{l}\text { Protection of trenches } \\
\text { with use of } \\
\text { herpetological fences } \\
\text { Narrowing the } \\
\text { construction belt } \\
-2\end{array}$ & $\begin{array}{l}\text { Protection of trenches } \\
\text { with use of } \\
\text { herpetological fences } \\
-1\end{array}$ & $\begin{array}{l}\text { Protection of trenches } \\
\text { with use of } \\
\text { herpetological fences } \\
\text { Narrowing the } \\
\text { construction belt } \\
-2\end{array}$ & $\begin{array}{l}\text { Protection of trenches } \\
\text { with use of } \\
\text { herpetological fences } \\
-1\end{array}$ \\
\hline \multirow{2}{*}{$\begin{array}{l}0 \\
\frac{0}{0} \\
8 \\
0 \\
.0 \\
0 \\
0 \\
0\end{array}$} & $\begin{array}{l}\text { Safety issues in the } \\
\text { vicinity of the } \\
\text { construction site }\end{array}$ & -2 & -1 & -2 & -1 \\
\hline & Landscape factors & -2 & -1 & -2 & -1 \\
\hline \multirow{5}{*}{ 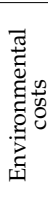 } & Air & -2 & -1 & -2 & -1 \\
\hline & Soil & -2 & -1 & -2 & -1 \\
\hline & Water & -1 & 0 & -1 & 0 \\
\hline & Physical factors & -1 & -3 & -1 & -3 \\
\hline & Natural factors & -1 & 0 & -1 & 0 \\
\hline \multicolumn{2}{|c|}{$\begin{array}{l}\text { Other-limiting the duration } \\
\text { of construction works }\end{array}$} & $\begin{array}{l}\text { Optionally, considering } \\
\text { the interruption of } \\
\text { works for the breeding } \\
\text { season of birds, } \\
\text { amphibians, and reptiles } \\
-2\end{array}$ & $\begin{array}{l}\text { Optionally, considering } \\
\text { the interruption of } \\
\text { works for the breeding } \\
\text { season of birds, } \\
\text { amphibians, and reptiles } \\
-2\end{array}$ & $\begin{array}{l}\text { Optionally, considering } \\
\text { the interruption of } \\
\text { works for the breeding } \\
\text { season of birds, } \\
\text { amphibians, and reptiles } \\
-2\end{array}$ & $\begin{array}{l}\text { Optionally, considering } \\
\text { the interruption of } \\
\text { works for the breeding } \\
\text { season of birds, } \\
\text { amphibians, and reptiles } \\
\quad-2\end{array}$ \\
\hline \multicolumn{2}{|r|}{ TOTAL WEIGHTS } & -19 & -12 & -19 & -12 \\
\hline
\end{tabular}

In order to perform an accurate comparison of the evaluations of the open-cut method with the trenchless method using the horizontal directional drilling (HDD) technology, it seems necessary to take into account numerous environmental and social factors. The overall score for the open excavation method obtained with use of the AHP multi-criteria evaluation is, for different variants, approximately -19 , while the evaluation of the realisation of gas pipeline with use of the Horizontal Directional Drilling method gives a score from -15 to -10 , depending on the section.

The technological costs for the analysed sections of the gas pipeline are usually lower for trenchless methods than for the open cut method and they reach, on the average, a score of -2 for the HDD method, compared to -4 to -3 for the trenchless method. Different economic conditions apply to structures that cross under rivers or pass through very sensitive areas with a dense underground infrastructure or ground waters. The technology used in the trenchless method can locate the construction site in a small area. Consequently, the resulting damage to the road paving, private property, and existing infrastructure is minimal, which reduces the high economic costs. 
On the other hand, social costs prove to be directly proportional to the surface area occupied by the construction site- the larger the area, the higher the risk to which the workers are exposed. Usually, small excavations and a small project area means that the equipment is better and safety measures are followed more correctly. As a result, as the construction site area is significantly larger for the open excavation method than for the trenchless method, the costs of the first one are higher and are evaluated as -2 , while for the HDD method the typical score is -1 .

Due to the fact that investment realised with use of the HDD method is constructed underground, the transformation of specific components of the environment caused by construction works may be reversed after the project has been completed. Thus, environmental costs for the trenchless method were assigned a higher score. For works performed with use of the open-cut method, the time required to restore the original state of the environment is longer. This reflects the time that is needed for the trees and bushes removed from the installation belt to grow back (except for the 4-meter-controlled zone in forest areas and the 6-meter zone outside the forests). If the trenchless method is selected, trees will be cut outside the most valuable natural areas and in a narrower zone than that required for the open excavation method. On the sections of the gas pipeline constructed with use of the trenchless HDD method, it is not absolutely necessary to cut the trees in the controlled zone of the pipeline. Here, the differences in scores are the highest (Figure 2).

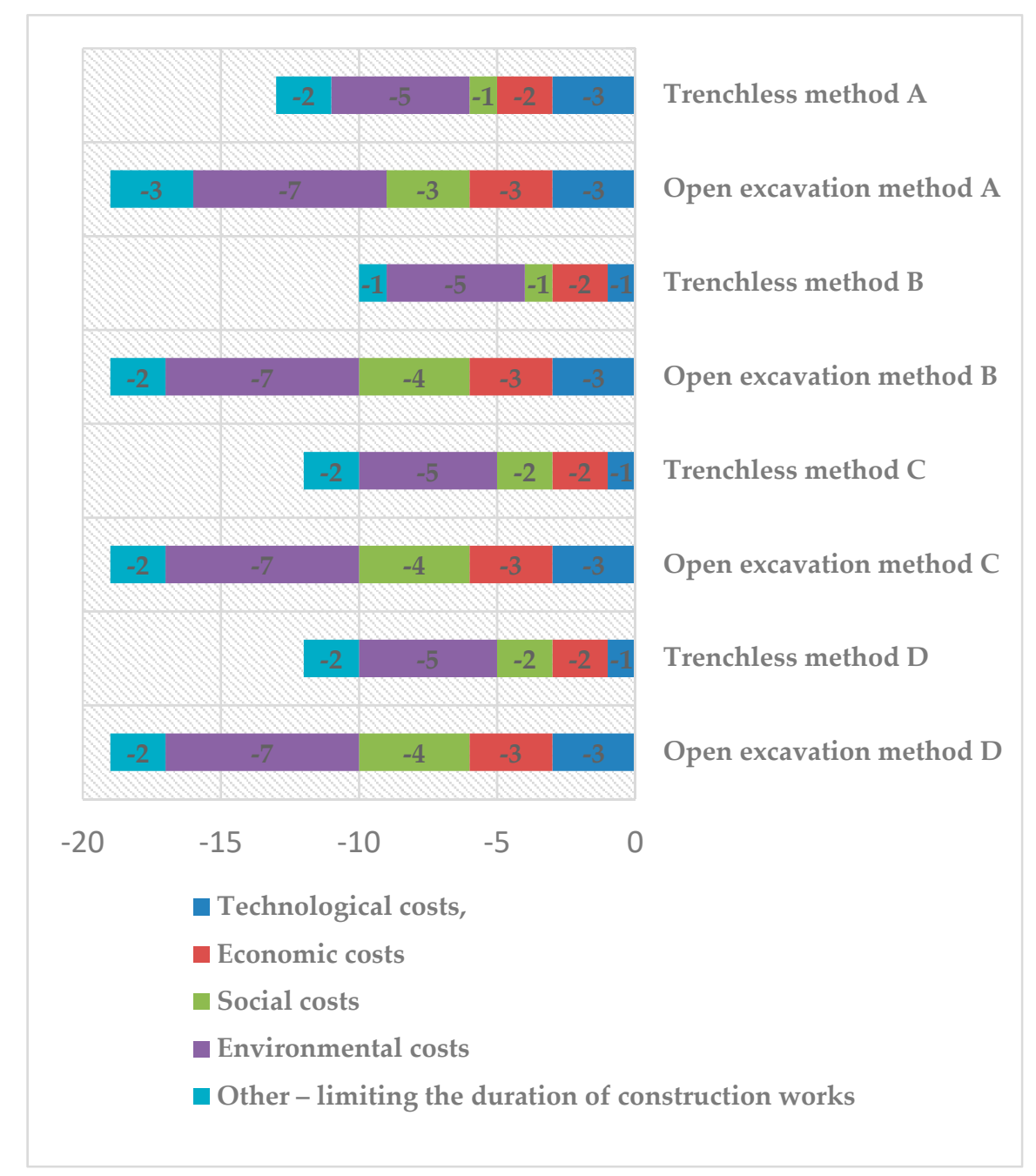

Figure 2. Comparison of the variants A-D of realisation of selected sections of the gas pipeline in the Analytic Hierarchy Process (AHP). 
For the purposes of the discussed investment, the sections marked in Table 1 as $C$ and D were ultimately selected to be realised with use of the horizontal directional drilling (HDD) method.

Thanks to the adopted method of crossing water courses, ponds, and the most valuable habitats with use of the HDD method, the realisation of the investment will not pose a threat for habitats and species of plants and animals that are protected as part of Natura 2000 areas, and it will not disturb the integrity of protected areas.

\section{Conclusions}

The analysis of the technological, economic, social, and environmental costs of the realisation of the investment with respect to the compared methods of realisation of the pipeline sections enables the selection of the most beneficial variant of construction. The analysed sections $C$ and $D$ of the gas pipeline were finally selected for realisation with use of the trenchless method. In the analysis, they were both assigned a score of -12 for the trenchless method, while the open excavation method for sections $C$ and D scored -19 . These sections include Alluvial forests with Alnus glutinosa and Fraxinus excelsior (Alno-Padion, Alnion incanae, Salicion albae) 91E0 at a length of $500 \mathrm{~m}$, and Alluvial forests with Alnus glutinosa and Fraxinus excelsior (Alno-Padion, Alnion incanae, Salicion albae) 91E0 with the Natura 2000 area Kumaki Dobrej and a $650 \mathrm{~m}$ long marsh.

The multi-criteria analysis, i.e., the Analytic Hierarchy Process (AHP) applied for the evaluation of investments related to the realisation of a high-pressure gas pipeline, provided an answer to the question posed: Are the technological and economic costs of the application of the open excavation method used in the construction of a high-pressure gas pipeline really lower than in the horizontal directional drilling (HDD) method, with higher environmental costs?

Research revealed that the technological costs of the open excavation method are, in all cases, higher that the technological costs of the HDD method during the realisation of a gas pipeline. On the other hand, the economic costs are comparable, with a slight advantage for the HDD method. The second part of the thesis was confirmed by the multi-criteria evaluation of the planned investments.

As a result of accepting the HDD trenchless method for realisation, the negative impact on nature and the environment has been minimised. The practical example of attribute assessment demonstrated that the HDD technology is preferable in comparison with the open excavation method. The structure of the AHP method allows the participants of the project to understand the obtained results and enables conducting further analyses, whether result or sensitivity analysis. The results enable us to answer Question 2: Can the environmental and social costs of constructing high-pressure gas pipelines influence the decision on the application of the trenchless method (horizontal directional drilling (HDD)) for the construction of gas pipelines in naturally valuable areas?

Currently, the horizontal directional drilling technology is becoming a popular method of constructing underground technical infrastructure networks in developed areas or valuable natural areas. This is a low-waste technology, and the use and management of a closed cycle of drilling liquid is recommended [44]. In addition to the benefits that HDD provide for the logistics of site clean-up, it also delivers sustainability advantages compared to alternative construction methods [52].

Similarly, the application of trenchless methods or those that ensure that the soil and water relations in other naturally sensitive areas (such as wetlands, etc.) will not be disturbed will reduce the impact of the planned construction works on the natural values of such areas. The HDD technique provides significant benefits for urban environments by decreasing the disruption caused by street excavations [53].

Thus, one may conclude that the realisation of the investment at the proposed location and with use of trenchless construction methods in areas with high natural values is the most beneficial variant for the environment.

Author Contributions: Conceptualization, U.K.-K. and M.H.; methodology, U.K.-K.; validation, M.H.; formal analysis, U.K.-K.; investigation, M.H.; resources, U.K.-K. and M.H.; data curation, U.K.-K.; writing一original 
draft preparation, U.K.-K. and M.H.; writing—review and editing, M.H. and U.K.-K.; visualization, U.K.-K.; supervision, M.H.; funding acquisition, M.H.

Funding: This research was funded by the Department of Spatial Economy of the Wrocław University of Environmental and Life Sciences from statutory funds.

Conflicts of Interest: The authors declare no conflict of interest.

\section{References}

1. Saaty, T.L. The Analytic Hierarchy Process; Mcgrew Hill, New York, International, Translated to Russian, Portuguesses and Chinese, Revised edition, Paperback, 2000; RWS Publications: Pittsburgh, PA, USA, 1996.

2. Saaty, T.L. Decision Making for Leaders: The Analytic Hierarchy Process for Decisions in a Complex World; RWS Publications: Pittsburgh, PA, USA, 1990.

3. Asgari, N.; Hassani, A.; Jones, D.; Nguye, H.H. Sustainability ranking of the UK major ports: Methodology and case study. Transp. Res. Part E Logist. Transp. Rev. 2015, 78, 19-39. [CrossRef]

4. Saaty, T.L.; Vargas, L.G. Models, Methods, Concepts and Applications of the Analytic Hierarchy Process; Kluwer Academic Publishers: Boston, MA, USA, 2000.

5. Saaty, T.L. Rank from Comparisons and from Ratings in the Analytic Hierarchy, Network Processes; University of Pittsburgh: Pittsburgh, PA, USA, 2000.

6. Saaty, T.L. Creative Thinking, Problem Solving \& Decision Making; RWS Publication: Pittsburgh, PA, USA, 2001.

7. Saaty, T.L. Deriving the AHP 1-9 scale from first principles. In Proceedings of the ISAHP, Berne, Switzerland, 2-4 August 2001.

8. Saaty, T.L. How to Make a Decision: The Analytic Hierarchy Process. Interfaces 1994, 24, 19-43. [CrossRef]

9. Rosmuller, N.; Beroggi, G.E.G. Group decision making in infrastructure safety planning. Saf. Sci. 2004, 42, 325-349. [CrossRef]

10. Skorupski, J. Multi-criteria group decision making under uncertainty with application to air traffic safety. Expert Syst. Appl. 2014, 41, 7406-7414. Available online: http://skorupski.waw.pl/publikacje/MultiCriteria\%20Group\%20Decision\%20Making\%20Under\%20Uncertainty\%20with\%20Application\%20to\% 20Air\%20Traffic\%20Safety.pdf (accessed on 20 March 2019).

11. Roszkowska, E. Multi-criteria decision making models by applying the topsis method to crisp and interval data. In Multiple Criteria Decision Making 10-11; Trzaskalik, T., Wachowicz, T., Eds.; The University of Economics in Katowice: Katowice, Poland, 2011; Available online: http://mcdm.ue.katowice.pl/files/mcdm11.pdf (accessed on 20 March 2019).

12. Lai, Y.J.; Liu, T.Y.; Hwang, C.L. TOPSIS for MODM. Eur. J. Op. Res. 1994, 76, 486-500. [CrossRef]

13. Jahanshahloo, G.R.; Hosseinzadeh, L.F.; Izadikhah, M. An algorithmic method to extend TOPSIS for decision-making problems with interval data. Appl. Math. Comput. 2006, 175, 1375-1384. [CrossRef]

14. Hwang, C.-L.; Yoon, K. Multiple Attribute Decision Making. Lecture Notes in Economics and Mathematical Systems 186; Springer: Berlin, Germany, 1981; Available online: https://www.springer.com/gp/book/9783540105589 (accessed on 10 April 2019).

15. Trzaskalik, T.; Wydział Informatyki i Komunikacji; Uniwersytet Ekonomiczny w Katowicach. Wielokryterialne wspomaganie decyzji. Przegląd metod i zastosowań. Zeszyty Naukowe Politechniki Śląskiej Seria Organizacja Zarządzanie 2014, z. 74, 239-263. Available online: http://www.woiz.polsl.pl/znwoiz/ z74/2_11_Trzaskalik_T_po_recenzji_final.pdf (accessed on 10 April 2019).

16. Roszkowska, E.; Wachowicz, T. Application of fuzzy TOPSIS to scoring the negoti ation offers in illstructured negotiation problems. Eur. J. Op. Res. 2015, 242, 920-932.

17. Roszkowska, E.; Wachowicz, T. Ocena ofert negocjacyjnych spoza dopuszczalnej przestrzeni negocjacyjnej. Prace Naukowe Uniwersytetu Ekonomicznego Wrocławiu 2015, 385, 202-209. [CrossRef]

18. Roszkowska, A.; Filipowicz-Chomko, M.; Wachowicz, T. Wykorzystanie metody TOPSIS do oceny zróżnicowania rozwoju województw Polski w latach 2010-2014 w kontekście kształtowania się ładu instytucjonalnego [The Application of TOPSIS Method for the Evaluation of Diversification of Polish Voivodeships between 2010-2014 in the Context of Forming of Institutional]. Prace Naukowe Uniwersytetu Ekonomicznego Wroctawiu 2017, 469, 149-158. Available online: https://www.researchgate.net/publication/ 322581029_Wykorzystanie_metody_TOPSIS_do_oceny_zroznicowania_rozwoju_wojewodztw_Polski_w_ latach_20102014_w_kontekscie_ksztaltowania_sie_ladu_instytucjonalnego (accessed on 10 April 2019). 
19. Jahanshshloo, G.R.; Hosseinzadeh Lotfi, F.; Izadikhah, M. Extension of the TOPSIS method for decision-making problems with fuzzy data. Appl. Math. Comput. 2006, 181, 1544-1551. [CrossRef]

20. Trzaskalik, T. Modelowanie preferencji w wielokryterialnych dyskretnych problemach decyzyjnych [Preference modelingin multicriteria discrete decision making problems]. Prace Naukowe Uniwersytetu Ekonomicznego Wrocławiu [Res. Pap. Wroc. Univ. Econ.] 2016, 426. [CrossRef]

21. Tecle, A. Choice of Multi-Criteria Decision-Making Techniques for Watershed Management. Ph.D. Thesis, University of Arizona, Tuscon, AZ, USA, 1988. Available online: https://www.researchgate.net/publication/ 35576215_Choice_of_Multicriterion_Decision_MakingTechniques_for_Watershed_Management (accessed on 10 April 2019).

22. Tzeng, G.H.; Huang, J.J. Multiple Attribute Decision Making. Methods and Applications; CRC Press: London, UK, 2011.

23. Zalewski, W. Zastosowanie metody TOPSIS do oceny kondycji finansowej spółek dystrybucyjnych energii elektrycznej [Application of TOPSIS method for evaluation of financial condition of the power distribution companies]. Econ. Manag. 2012, 4, 137-145. Available online: http://jem.pb.edu.pl/data/magazine/article/103/ en/4.1_zalewski.pdf (accessed on 9 April 2019).

24. Gershon, M. Model Choice in Multi-Objective Decision-Making in Natural Resource Systems. Ph.D. Thesis, University of Arizona, Tuscon, AZ, USA, 1981.

25. Briggs, C.A. Risk Assessment in the Upstream Crude Oil Supply Chain: Leveraging Analytic Hierarchy Process. Ph.D. Thesis, North Dakota State University, Fargo, ND, USA, 2010. (UMI No. 748837971).

26. Deason, K.S.; Jefferson, T. A systems approach to improving fleet policy compliance within the US Federal Government. Energy Policy 2010, 38, 2865-2874. [CrossRef]

27. Steele, K.; Carmel, Y.; Cross, J.; Wilcox, C. Uses and misuses of multicriteria decision analysis (MCDA) in environmental decision-making. Soc. Risk Anal. 2009, 29, 26-33. [CrossRef] [PubMed]

28. Kozioł, W.; Piotrowski, Z.; Pomykała, R.; Machniak, Ł.; Baic, I.; Witkowska-Kita, B.; Lutyński, A.; Blaschke, W. Zastosowanie analitycznego procesu hierarchicznego (AHP) do wielokryterialnej oceny innowacyjności technologii zagospodarowania odpadów z górnictwa kamiennego. Rocznik Ochrona Środowiska 2011, 13, 1619-1634. Available online: https://ros.edu.pl/images/roczniki/archive/pp_2011_103.pdf (accessed on 27 December 2018).

29. Imam, E.; Tesfamichael, G.Y. Use of remote sensing, GIS and analytical hierarchy process (AHP) in wildlife habitat suitability analysis. J. Mater. Environ. Sci. 2013, 4, 460-467. Available online: http: //www.jmaterenvironsci.com/ (accessed on 12 April 2019).

30. Aragonés-Beltrán, P.; Chaparro-González, F.; Pastor-Ferrando, J.P.; Pla-Rubio, A. An AHP (Analytic Hierarchy Process)/ANP (Analytic Network Process)-based multi-criteria decision approach for the selection of solar-thermal power plant investment projects. Energy 2014, 66, 222-238. [CrossRef]

31. Grošelj, P.; Malovrh, Š.; Stirn, L.Z. Methods based on data envelopment analysis for deriving group priorities in analytic hierarchy process. Cent. Eur. J. Oper. Res. 2011, 19, 267-284. [CrossRef]

32. Křupka, J.; Provazníková, R.; Švejcar, J. Multiple criteria decision analysis of EU project implementation benefits for the impacted micro-region. Int. J. Math. Model. Methods Appl. Sci. 2011, 5, 1354-1362. Available online: http://www.naun.org/. (accessed on 12 April 2019).

33. Roux, I.J. Applying the Analytic Hierarchy Process to Oil Sands Environmental Compliance Risk Management. Ph.D. Thesis, Walden University, Minneapolis, MN, USA, 2015. Available online: https://scholarworks. waldenu.edu/cgi/viewcontent.cgi?article=1163\&context=dissertations (accessed on 28 December 2018).

34. Saaty, T.L. Fundamentals of Decision-Making and Priority Theory with the Analytical Hierarchy Process Vol. VI of the AHP Series; RWS Publications: Pittsburgh, PA, USA, 2006. [CrossRef]

35. Saaty, T.L.; Zoffer, H.J. Nina's decision: How to make better decisions and resolve conflicts. Int. J. Anal. Hierarchy Process 2012, 4, 78-86. Available online: http://www.ijahp.org/ (accessed on 12 April 2019).

36. Talib, F.; Rahman, Z.; Qureshi, M.N. Prioritizing the practices of total quality management: An analytic hierarchy process analysis for the service industries. Total Qual. Manag. Bus. Excell. 2011, 22, 1331-13510. [CrossRef]

37. Castro, D.M.; Parreiras, F.S. A review on multi-criteria decision-making for energy efficiency in automotive engineering. Appl. Comput. Inform. 2018. [CrossRef]

38. Ho, W.; Xu, X.; Dey, P.K. Multi-criteria decision making approaches for supplier evaluation and selection: A literature review. Eur. J. Oper. Res. 2010, 202, 16-24. [CrossRef] 
39. Chen, Y.; Liu, R.; Barrett, D.; Gao, L.; Zhou, M.; Renzullo, L.; Emelyanova, I. A spatial assessment framework for evaluating flood risk under extreme climates. Sci. Total Environ. 2015, 538, 512-523. [CrossRef]

40. Govindan, K.; Rajendran, S.; Sarkis, J.; Murugesan, P. Multi criteria decision making approaches for green supplier evaluation and selection: A literature review. J. Clean. Prod. 2015, 98, 66-83. [CrossRef]

41. Javid, R.J.; Nejat, A.; Hayhoe, K. Selection of $\mathrm{CO}_{2}$ mitigation strategies for road transportation in the United States using a multi-criteria approach. Renew. Sustain. Energy Rev. 2014, 38, 960-972. [CrossRef]

42. Párez, J.C.; Carrillo, M.H.; Montoya-Torres, J.R. Multi-criteria approaches for urban passenger transport systems: A literature review. Ann. Oper. Res. 2014, 226, 69-87. [CrossRef]

43. Dağdeviren, M. Decision making in equipment selection: An integrated approach with AHP and promethee. J. Intell. Manuf. 2008, 19, 397-406. [CrossRef]

44. Kwast-Kotlarek, U.; Hełdak, M.; Szczepański, J. Introducing bentonite into the environment in the construction stage of linear underground investment using the HDD method. Appl. Sci. 2018, 8, 2210. [CrossRef]

45. Zwierzchowska, A. Technologie Bezwykopowej Budowy Sieci Gazowych, Wodociagowych i Kanalizacyjnych; Wydawnictwo Politechniki Świetokrzyskiej: Kielce, Polska, 2006. (In Polish)

46. Ariaratnam, S.T. Perspektywy globalnego wpływu technologii bezwykopowych na rozwój gospodarczy. Nowoczesne Budownictwo Inżynieryjne. 2012, 2, 62-66. Available online: http://www.nbi.com.pl/assets/NBI-pdf/ 2012/2_41_2012/pdf/15_samule_ariaratnam_wplyw_technologii_bezwykopowych_na_gospodarke.pdf (accessed on 20 March 2019).

47. Chojnacki, A.; Szwedo, O. Wybór systemu klasy ERP metoda AHP [An AHP method to ERP system selection]. Biuletyn Instytutu Systemów Informatycznych 2010, 5, 13-22. Available online: file://C:/Users/KGP/Downloads/ httpwww_bg_utp_edu_plartbisi52010bisi520101322.pdf (accessed on 9 April 2019).

48. Kuliczkowski, A.; Zwierzchowska, A. The optimization of trenchless pipe laying technologies and the specificty of pipe laying in urban conditions. Struct. Environ. 2010, 2, 31-38.

49. Allouche, E.N.; Ariaratnam, S.T.; Lueke, J.S. Horizontal directional drilling: Profile of an emerging industry. J. Constr. Eng. Manag. 2000, 126, 68-76. [CrossRef]

50. Atalah, A.; Kariuki, J. Cost comparison between horizontal directional drilling and open-cut construction methods in Nairobi, Kenya. In Proceedings of the International Conference on Pipelines and Trenchless Technology (ICPTT) 2009, Shanghai, China, 18-21 October 2009. [CrossRef]

51. Vilfrant, E.C. Analysis of Parameters Affecting Costs of Horizontal Directional Drilling Projects in the United States for Municipal Infrastructure. Master's Thesis, Arizona State University, Phoenix, AZ, USA, December 2010. Available online: https://repository.asu.edu/attachments/56065/content/Vilfrant_asu_0010N_10038.pdf (accessed on 20 March 2019).

52. Michael, D.; Lubrecht, L.G. Horizontal directional drilling: A green and sustainable technology for site remediation. Environ. Sci. Technol. 2012, 46, 2484-2489. [CrossRef]

53. Manacorda, G.; Miniati, M.; Bracciali, S.; Dei, D.; Scott, H.F.; Koch, E.; Pinchbeck, D.; Murgier, S. Development of a bore-head GPR for Horizontal Directional Drilling (HDD) equipment. In Proceedings of the 13th International Conference on Ground Penetrating Radar, Lecce, Italy, 21-25 June 2010.

(C) 2019 by the authors. Licensee MDPI, Basel, Switzerland. This article is an open access article distributed under the terms and conditions of the Creative Commons Attribution (CC BY) license (http://creativecommons.org/licenses/by/4.0/). 